\title{
The discursive organization of research interviews
}

\begin{abstract}
The article discusses two methods for assessing beliefs, values etc. and underlying factors, viz. structured and semi-structured interview. The application of semi-structured interviews is exemplified in connection with a study carried out by the author, emphasising especially the role of accounts for assessing factors underlying beliefs, judgements, etc.
\end{abstract}

\section{The research interview as a dialogue}

The semi-structured research interview is a widely used research instrument in social sciences, the aim being to gain knowledge about how people give meaning to their worlds in social interaction. Compared to the structured interview, which is often used to verify what people's behavior, opinions, beliefs, values, etc. are at any moment (a case in point is the European Value Surveys), the semi-structured interview enables us to investigate the underlying factors that might determine such phenomena. It cannot be ignored, however, that the semi-structured interview itself is interaction, whatever is the methodology used, and no matter how carefully we try to eliminate interpersonal influences between interviewer and respondent. If it is to be considered a valid and reliable research instrument it is therefore necessary to examine how the joint construction of the interview between interviewer and respondent influences the kind of knowledge produced. The aim of this paper is to explore interactive phenomena in the discursive construction of interviews, in particular the negotiation of membership categories in accounts.

* Annette Grindsted

Institute of Language and Communication

University of Southern Denmark

Campusvej 55

DK-5230 Odense $M$ 


\section{Methodology}

Contemporary changes in philosophical and theoretical positions within the social sciences from positivism to postmodern thinking have had important impacts on interviewing methodologies (Kvale 1996). To secure 'objectivity' the structured interview has been considered a valid and reliable research instrument. It has been assumed that standardized questioning behaviors ensure standardized answering behaviors, and standardization ensures validity since it depersonalizes communicative behavior. However, applying a discourse analytical approach to interview research, we are able to demonstrate how validity and the construction of meaning is seriously affected by the normative aspects imposed (Suchman \& Jordan 1990). Their study is directed towards especially questioning behaviors in structured interviews. On the one hand the interview rests upon basic principles for ordinary conversational organization, while at the same time imposing serious constraints on the application of the very same principles concerning e.g. coherence, relevance and cooperation. In this way the interviewer finds himself in a conversational dilemma in various ways. One such example is that he is prevented from showing that he is a careful and attentive listener since he has to follow pre-established questioning procedures that do not take into account the manifold ways in which respondents may engage in answering behaviors. Thus, he may have to pose questions that have already been answered (Houtkoop-Steenstra 1995, 1997, 2000). Another aspect concerns inferential work. In structured interviews, for the sake of statistical measuring and to facilitate comparability of data, respondents' replies should preferably be reduced to standardized, in many cases even prefabricated units, and these circumstances may prevent the interviewer from pursuing ambiguous or vague answers.

To illustrate the shift from a positivistic to a post-modern view on interviewing methodology, let us compare a few of the guidelines of the Southern Focus Poll Training Manual (1999) for conducting structured interviews with Kvale's description (1996) of the discursive organization aimed at in the semi-structured research interview. In the training manual cited above it is said that 'once you have obtained informed consent from the respondent, you need to avoid biasing the respondent in any way. Bias occurs when the respondent's true response is not recorded on the questionnaire. Some reasons for bias include: 
1. the interviewer influences the respondent through telling the respondent her or his personal opinions and prejudices during an interview.

2. the interviewer rewords the question in order to fit her or his perceptions of what the respondent is capable of understanding.

3. the interviewer attempts to interpret a question in response to a respondent's query.

To avoid bias, you should

1. read the questions exactly as worded

2. read each question slowly and enunciate clearly

3. ask the questions in the order that they were presented

4. ask all questions

5. repeat questions when they are misunderstood

6. use neutral probes and comments.' (p. 12)

As far as the discursive organization aimed at in the semi-structured research interview is concerned, Kvale (1996) observes that a semistructured research interview is a conversation between at least two interlocutors (interviewer and respondent) about a topic of mutual interest. The aim is knowledge production. To produce knowledge has nothing to do with searching an objective reality, but with gaining insights in how respondents socially construct reality focussing on the interpretation and negotiation of the meaning of the social world. The interview event is asymmetrical. The interviewer controls the situation, introduces main topics to be talked about and is able to control the interview process by asking more questions. One may say that the role of the interviewer is to elicit as much relevant information as possible and to make sure that he has properly understood respondent replies. But there is more to it than that. It is also the interviewer's job to secure that the interaction surpasses the limits of social talk and exchange of ideas. He should establish an atmosphere, in which the respondent feels safe and free to talk about his experience and feelings. This implies that although it is his job constantly to assess the quality of the replies, bearing in mind the objectives of the research project, he must at the same time observe ethical aspects involved in asking people rather personal and intimate questions (Kvale 1996). 
Once an interlocutor has accepted to engage in a research interview, he is accountable to the interviewer for his replies. He has committed himself to answer questions to the best of his abilities. To be a socially accountable respondent he must show sufficient care and effort in his replies. Since he through his replies represents everyday activities he must be concerned with veracity. But he must also be concerned with cooperating in the organization of the interaction process and with his relationship to the interviewer (Buttney 1993).

Turning to the question of how to do linguistically based research in the semi-structured interview, one of the theoretical foundations in discourse analysis is that since the construction of the social world takes place in conversation and since conversation is negotiation of meaning, the knowledge produced during an interview is not produced by the respondent but between interviewer and respondent. And since knowledge production is inter-relational the whole issue of how to secure validity and reliability must be revised. Therefore the point of departure ought to be that since interviewer behavior inevitably affects respondents' replies, let's face it and see what comes out of it.

In a true interactional approach to the study of how interviews are constructed one important question to be addressed is the way in which interpersonal relations between interviewer and respondent affect knowledge production. If we accept the idea that the construction of the social world takes place in the local management of context and meaning in conversation and that the interview is an interactional event where the knowledge produced is inter-relational, we also have to accept that not only does the interviewer influence how questions are delivered, but also that the respondent influences how questions are designed. And at this point one may argue that research on research interviewing has been biased focussing more on the interviewer than the respondent perspective. A case in point is Kvale's statement (1996) that in the design of questions both the thematic and the dynamic dimension have to be taken into account. Thematically the interview questions should produce knowledge that can be used to answer the research questions that form the basis for the research project itself, and dynamically the questions should be designed so as to establish a positive interaction space. But why not use the same distinction when it comes to how respondents construct replies? 


\section{Data description and analytic scope}

These general observations about the thematic and interactive dimensions of the semi-structured research interview serve as a point of departure for explaining how these two interlocutors jointly manage to construct the interview from a discourse analytical perspective. As far as the thematic level is concerned the interviews that serve as the empirical base for the present study is about people's stereotypic beliefs and cultural identities and their importance in daily work at the intercultural workplace. The thematic dimension appears clearly from the interview guide ${ }^{1}$. It contains 17 questions concerning inter-group perceptions on workrelated issues centering round goal-oriented activities in the intercultural workplace. The questions are of two types. One is about specific category features related to interactive concepts regulating the interrelationship between 'ego' and 'alter' (e.g. politeness, trust, cooperation, assertiveness). The other type concerns the respondents' perception of how specific types of interactive events are organized (e.g. meetings, negotiations). Consequently, when setting up response slots, the respondents put words to their stereotypic beliefs, both concerning in-group and out-group. In these representations it turns out that the respondents have passed through a wide range of cognitive processes on how they give their worlds meaning. These processes include membership categorization, value attribution, stereotype maintenance, and identity expression (Grindsted, 2000).

As far as the interactive organization is concerned the interviews were based on a questionnaire with a number of questions that the interviewer would endeavor to run through before the interview was concluded. The order in which the questions were asked did not have to be followed. Additional questions (not only for clarification purposes) were allowed to be asked, and the interviewers were even allowed and expected to give feed-back to, or comment upon, the respondents' answers. Allowing the interviewer to engage in such activities contributed to giving an appearance of spontaneous conversation (Mazeland; ten Have (1998).

\footnotetext{
1 The interviews were made on the basis of an interview schedule prepared by prof. Lars Fant, Stockholm University, and carried out by a research team consisting of Lars Fant, Adriana Bolívar, Univsersidad Central de Caracas, and myself. The interviews were carried out in Danish and Swedish owned companies in Venezuela and Mexico
} 
Turning to the analytic scope of the project, the interview texts do not merely refer to some reality beyond the text, the interaction between the interlocutors is of interest in its own right. In delimitating our analytic concerns our argument runs as follow: Following Antaki and Widdicombe (1998) a person can be a member of an infinity of categories, and each category will imply that he or she possesses this or that range of characteristics. Consequently, one question to be raised by the researcher is the circumstances under which national identity emerges as a relevant category, and to which degree category features are negotiated, accepted or rejected.

Another research question concerning the interactive management of the interview is whether we can find recurrent features in the ways in which interviews are constructed whatever the topic of the interview may be. If we look at the question 'Do you think the Danes are very polite or not very polite?' it is meant to be treated differently in the structured and semi-structured interview, respectively. In a structured interview a minimal response like 'they are not very polite' that is easy to categorize would be considered a preferred response. In the semistructured interview, on the other hand, it is clearly a dispreferred response option, in the first place because it doesn't appear what politeness means to the respondent, and secondly because the respondent does not explain why Danes are not polite in their interaction with others. Semi-structured interviews invite to generate accounts, i.e. turn constructional units that explain or justify a position. Therefore, it needs to be analyzed how the interlocutors jointly manage to construct accounts.

\subsection{What is an account?}

In general terms account refers to the thematic dimension of talk meaning 'description', 'reason for', 'explanation' or 'self-reports' about everyday activities, other persons or personal relationships. What happened? Why did it happen? Who caused it to happen? What does the accounter think about the actor? What does the accounter think the accounted person thinks about him, etc.? In their study of interview data Hutchby and Wooffitt (1998) see accounts as long uninterrupted stretches of talk that may consist of anecdotes, explanations, stories and so on.

Following Hutchby and Wooffitt (1998) it is not so simple to develop an interactive perspective on the construction of accounts, because of 
the problem of isolating a unit of lengthy stretches of talk produced by a respondent with little or no contributions from the interviewer. In normal conversation action sequences emerge from the production of alternative turns by interlocutors. But how can we identify the sequential properties of monologic utterances with no analytic unit at hand? How can we claim that these almost one-speaker accounts have an interactional orientation? By way of answering these questions our point of departure has been to see accounts as the text sequences produced between interview schedule questions. In this way, the notions of turn-taking, sequential organization, and conversational negotiation may still be used to show, at least to some degree, how talk is interactionally accomplished in interview contexts.

One of the main features of the interview as an interactive event is the pre-allocated turn-taking system. The interactive roles of interviewer and respondent are to pose questions and produce replies. Even with these restrictions, however, it turns out that the allocation of turns at speaking is not automatically achieved. Sequential organization refers to matters of contiguity. What is said in one utterance sets up expectations about what is to follow afterwards. In an interview, once a question has been raised by the interviewer, the respondent is constrained to reply or at least acknowledge expectations raised in the question. Conversational negotiation refers to processes by which not only shared understanding are arrived at but also to interactive tasks like turn-taking and sequentiality mentioned above. Negotiation is achieved indirectly through different interlocutors' turns as a kind of byproduct of the task of conveying content. In this way, responses are not simply answers to questions but also a reflection of the interviewer's assessment of whether a respondent has said enough for the purpose at hand and the respondent's willingness or ability to add more information.

The statement that the interview is constructed jointly by interviewer and respondent implies that questions and responses are formulated in, developed through, and shaped by the interaction between interviewers and respondents. In this way Mishler (1986) shows a number of ways through which meanings of questions and responses may be achieved from successive reformulations by interviewers and respondents until they arrive at an acceptable level of shared agreement to the insistence of interviewers on their definitions, because they are influenced by a 
priori assumptions about adequacy. A case to the contrary is Hutchby and Wooffitt's report (1998) on Wooffitt's project on semi-structured interviews on group membership and identification, where they analyzed the first exchanges. The opening question was designed to elicit a subcultural self-categorization. Many respondents immediately did affirm the relevance of that kind of social identity. However, in several cases, the respondents' first turn was some kind of dispreferred answer. They portrayed themselves as 'not seeing the category relevance of the interviewer's first turn', and in this way they rejected the validity of the basis on which they were selected for the interview. So on the basis of the interactional management on category ascription, resistance and affiliation they were able to make some critical points on the assumptions underlying social identity theory and the purchase it affords on understanding processes of group affiliation and self-categorization (Hutchby \& Wooffitt 1998).

For the purposes of the present study it should be pointed out that a respondent cannot produce an account without having something to account for. This implies that to count as an account a stretch of talk should possess argumentative properties that explains or justifies why a certain position is taken. A respondent can be held responsible to produce a response, but he cannot be supposed to produce accounts, even if he is invited to do so. Whether an account is produced or not is something that may be negotiated between the parties. It has already been claimed that the semi-structured research interview is designed to produce accounts. It is therefore more accurate to describe the preferred discourse identities of interviewer and respondent as that of accounts recipient and accounter instead of questioner and answerer. One phenomenon which has been made subject to analysis is whether interviewer and respondent jointly manage to produce accounts or not.

The semi-structured research interview is often used for information gathering because it allows for a less imposing, more natural and spontaneous way of interacting. It cannot be ignored, however, that to ask a question in itself is a very powerful way of eliciting information. Very often a respondent will accept without hesitation the premises on which a question is built. In the present study the questions rest on the presupposition that national identity is a relevant membership category to account for differences in communicative behavior at the intercultural 
workplace. Even the category features are introduced by the interviewer. In this way interactive phenomena to be analyzed are the negotiation of national identity as a relevant category and of relevant category features.

\section{Analysis}

The analysis of our data reveals that the preferred exchange format is a closed question (e.g. Do you think the Danes are polite or not very polite?) followed by a response that consists of at least two turn constructional units. The first is a minimal response confirming or disconfirming the category features introduced by the questions (e.g. I don't think the Danes are very polite' and the second an account that justifies or explains the position taken (e.g. because they think they are superior and they only give orders). The analysis also reveals that in the joint construction of accounts national identity and the category features introduced by the interviewer do not always turn out to be relevant to explain perceived differences in communicative behaviors. In the following, three examples will be analyzed along these lines. In the first place we will examine the resources the interlocutors recur to in the interactive management of account construction. In the second place we will analyze how the membership categories and category features introduced in questions are treated.

\section{Example 1}

Interviewer: A(driana)

Respondent: M(iguel)

A: $\quad$ es interesante eso mira y qué opinas de la técnica argumentativa que ellos usan (.) es decir cómo presentan sus argumentos de manera eficiente o poco eficiente

\section{[}

M: $\quad$ sí muy directos muy directos

A:

son directos

M: sí seguramente directos bien objetivos en todo lo que es sus presentaciones o sea son presentaciones este que a lo mejor somos mientras nosotros somos emotivos y emocionales haciendo presentaciones que a lo mejor van a apelar::: a digamos a otro tipo de percepción eh a lo mejor inclusive damos más vueltas al asunto damos una antesala como pa:ra: ir digamos calentando nombres y todo lo demás no? ellos comienzan y dan sus resultados cifras resultados eso es lo importante 
A:

o sea lo que interesa son resultados logros

M: $\quad$ sí logros

A:

lo hecho

M:

claro

Translation:

A: it's interesting and look what do you think about the argumentation technique they use (.) I mean how do they present their arguments efficiently or not very efficiently

M:

yes very direct very direct

A:

they are direct

M: $\quad$ yes for sure direct pretty objective in every bit of their presentations that is it's presentations maybe we are emotive and emotional making presentations that will appeal to another type of perception you know maybe we even talk things over and over again and again we are paving the way to: let's say warm up names and all that you know they begin and present their results this is the important thing

A: $\quad$ you mean what is interesting is results achievements

M: ments

yes achieve-

A: $\quad$ things done

M:

that's it

The first part of $A$ 's turn ('this is interesting') is an assessment that marks that completion of the respondent's answer to the prior interview question is accepted. $A$ changes topic asking a new question from the interview schedule ('what do you think about their argumentation technique?') and to facilitate $M$ 's understanding of the question she reformulates it dichotomized. In this way she invites him to follow a specific line of thoughts, so she is, in fact, putting constraints on his reply scope. $M$ gives a minimal response about the Danes and their argumentation technique. They are very direct. This is repeated. Although $A$ posed the question in a closed format, she is not content with the answer, maybe because it is ambiguous, since it's unclear which part of the dichotomized question it refers to, maybe because she wants to elicit more information. Anyway, she reformulates the response ('they are very direct?'). This is sufficient 
to trigger off an account of why $M$ thinks they are direct in their argumentation. In the first place he makes a very broad generalization on different ways of perception. In the second place he is categorizing Danes and Venezuelans into different membership groups with different category features. Danes are objective and direct. The Venezuelans are emotional, and they beat about the bush and are person-oriented. The Danes are concerned with results and figures. $M$ marks completion by stating that what he has just said was what is important. In a way he is assessing the quality of his own account, and he signals that he is satisfied. The job $A$ is doing next may be to verify comprehension. She is constructing a question which is reformulated into a condensed version of the reply ('results', 'achievements', 'things done') and M confirms that she has understood him right.

Let us now look at an example from the Danish data to see if we can find similarities in the way in which the account is interactionally accomplished and membership categories and features are treated.

Example 2

Interviewer: A(nnette)

Respondent: L(ars)

A: $\quad$ ok (0.5) æhm (0.5) synes du de: hænger sig i formaliteter og:

L:

ja u'troligt meget

A:

det gør de

L: 'u'troligt meget

A: hvordan: kommer det så til udtryk i det daglige

[

L: ja altså især hvis de får en lille en lille smule øh: skal man sige en halv titel på ryggen eller et eller andet så: (.) æh jeg har haft et par eksempler hernede med en vi andre sad og grinede lidt af men ja da han lige pludselig han rykkede en en en grad op og (.) altså da så sku han jo ha sit eget kontor ikk og (.) gud døde mig om han ikk var inde og måle op om det var fem centimeter mindre end naboens ik og det

A:

L: altså det er jo til at skrige af grin af ikk men altså 
A: $\quad$ det er en sød lille historie (ler)

$\mathrm{L}$ : ja det det var det var vo sgu ved at dø af grin af (ler) hvor vi er ligeglade bare vi har en telefon og en computer og en fax ikk

A: ja

L: men han sku fanme ha et kontor der var nøj'agtig lige så stor som som: som sidemandens ikk og det var han inde at måle efter du både

[

A: $\quad$ (ler)

L: $\quad$ med tommestok og det hele så det må vi nok sige det går de sgu meget op i generelt altså nogen er selvfølgelig værre and andre ikk

A: jaja

L: $\quad$ jo men de går op i det

A: nu nævner du jo et eksempel ikk

L: jaja

A: det kan vi godt generalisere ud fra mener du

$\mathrm{L}:$ jo det jo generelt jo

A: er det nemt at: at opbygge et venskab

Translation:

A: ok (0.5) ehm (0.5) do you think they: stick to formalities and:

L: $\quad$ yes 'very much

A: they do

L: 've'ry much

A: how: does it reflect itself in daily life then

L:

yes well especially if they get a little a little bit er:: you could say half a title to show on their back or something like that then: (.) er: I've had some examples down here with a we others were laughing a bit but yes when he suddenly was promoted a a grade and (.) then he should have his own office you know and (.) by god if he didn't get into the office to measure if it was five centimetres smaller than that of his neighbour you know and it 
A: $\quad$ (laughing)

L: well we were killing ourselves with laughter but anyway

A: that's a funny little story (laughing)

L: $\quad$ yes it it was it was we were damned well on the point of killing ourselves with laughter (laughing) where we don't care if only we have a phone and a computer and a fax you know

A: yes

L: $\quad$ and then damn it he should have an office that was of exactly the same size as as: that of his neighbour you know and then he went in there to measure it both

A:

(laughing)

L: $\quad$ with a rule and everything so it we must say that they are damned interested in these things in general of course some are worse than others you know

A: oh yeah

[

L: yeah but they are interested in such things

A: now you give an example you know

L: yes yes

A: we can generalize from it do you think

L: yes it generally yes

A: is it easy to make friends with them

In the reformulation of the question from the interview schedule $A$ also takes into account the so called recipient design of her question. The 'ok' produced in her first turn marks that completion of the respondent's prior turn is accepted. What follows is therefore a topic change that bears no reference to the previous turn at all. To allow the respondent to adjust himself cognitively to another issue, $A$ produces a series of hesitation markers. In fact she tries to postpone turn allocation producing an even prolonged 'and' immediately after having made her question. Not until then does $L$ start generating his reply confirming with a reinforced minimal response that he thinks that the Venezuelans stick to formalities. Although the question format is closed, $A$ is not content with the response and tries to elicit more information by asking a question which is, in 
fact, a reformulation of $L$ 's reply ('they do?'), and since $L$ does nothing more than confirm his first reply, repeating its reinforcing part, $A$ once more tries to get more information, this time by asking a probe question ('how does is reflect itself in daily life?'). This question prompts $L$ to generate an account. One may hypothesize that the reason why $L$ chooses to deliver his account in anecdotic form, could be found in the last part of the probe question ('in daily life'). Anyway, he first produces a 'yeah but', to demonstrate that he has understood the question and is prepared to add the requested information. The subsequent part of his reply is a general statement in which he specifies the circumstances under which formality seems to be of importance. In a kind of preface ('I have had some examples down here') he announces that an anecdote will follow to support the veracity of his statement. He also announces that the anecdote will be set up in a joking format thus 'pre-inviting' $A$ to laugh. By exaggerating formulaic details about a Venezuelan colleague's behavior in a specific situation, he does induce $A$ to laugh. During the construction of his account he makes two tag questions to keep the interviewer's attention. $L$ produces a completion marker reformulating his joking format preface, and $A$ shows that she has understood it all. It might be her positive assessment of the account, which she infers to be a story, and her laughter that induce $L$ to reformulate his joking format preface once more and to expand on his account adding another dimension. What he does is to compare Venezuelans and Danes as two different membership groups in terms of divergent degrees of formality and to inform of how it is reflected in daily life. This leads him to repeat the gist of his story. He invites $A$ to laugh once more, and then he draws his final conclusion in which he confirms in a reformulated version his original minimal response to $A$ 's text question, although he modifies its generality. He produces a tag and $A$ 's response in the shape of a repeated 'yes' marks that she considers his response to be completed. $L$ marks completion by reformulating his previous conclusion. $A$ 's response implies that she is concerned with veracity, since she asks if this single example serves to illustrate the general picture. This is confirmed by $L$.

Now, what do these examples have in common? One question to be addressed concerns how interviewer and respondent show that they orient towards the construction of true, accurate and full accounts. Apart from the very last exchange in example 2 , in which the issue of veracity is 
explicitly addressed, do we find other features to the same effect? Crucial moments are to be located when new interview schedule questions are posed. In both examples the interviewers make an effort to design questions so as to facilitate comprehension on the part of respondents. If a question is not properly understood what might follow is the insertion of a time and energy wasting repair sequence, or at worst, a possible trouble source is left unattended. A recurrent feature of all interviews is that the first part of the respondent's turn is a minimal response to the text question. And very often, these minimal responses are followed by pauses. What is at issue here is of course the negotiation of turn taking. Does the interviewer accept the respondent's position of not accounting which would indeed be a dispreferred option from an interviewer perspective, or doesn't (s)he? If (s)he does not accept, (s)he can either display that (s)he is waiting for more information by not intervening in the pause, or (s)he may break it and say something. If (s)he chooses to break the pause (s)he will typically signal that (s)he is searching for common ground by redressing his/her next question in words or phrases just used by the respondent. This will normally prompt the respondent to generate an account.

Turning to the final part of account generation, how does the respondent signal completion? A recurrent feature is that the respondent returns to the initial part of his/her response, more specifically the minimal response referring to the statement (s)he was asked to account for. In doing so (s)he produces a kind of general conclusion or (s)he sums up or makes a kind of self-assessment of his/her response. The closing stage of response generation to text questions is also a crucial moment in any interview. The respondent is concerned with displaying that (s)he thinks (s)he has given a true, accurate and complete answer to the question, and it is the interviewer's last opportunity to solve problems of ambiguity, to ask the respondent to elaborate on specific points of his account, etc. In fact, the parties are negotiating if the text question has been adequately replied to. If both parties agree, the final part of the closing stage normally consists of one or more mutual confirmation exchanges.

If we turn to the process of negotiating the thematic dimension of interviewing, examples 1 and 2 suggest ways through which meanings of questions and responses may be arrived at. It should first be mentioned, however, that a recurrent feature of all text questions is the fact that they 


\section{8}

are very broad and general category features or open-ended questions about the organization of interactive events that should be used as a basis for categorizing memberships. What is often negotiated is not the relevance of the category features nor the interactive events themselves, but how they could be narrowed down to constitute precise and accurate descriptions of the two membership groups. If we return to example 1 about argumentation technique and efficiency the central part of the question concerns efficiency. What does it mean to be efficient in argumentation and what are the membership categorizations made in this respect? The features introduced by $M$ to categorize efficiency are directness, objectivity, figures and results as far as the Danes are concerned, and emotions and talk to characterize the Venezuelans. $A$ 's question of what is meant by results is interesting. She does not only ask the question but suggests herself new shades of meaning that could be attributed to the term results, namely achievements and to get things done. These new shades of meaning are immediately accepted by $M$. Although they are not explicitly treating the dimension of efficiency or inefficiency in argumentation, one is left with the impression that the cultural attributions made by $A$ and $M$ is that the Venezuelans are not very efficient 'argumentators' whereas the Danes are, since objectivity and achievements are to be valued, but emotionality and talk without action are not. In example $2 A$ accepts that $L$ sees formality as having something to do with titles and status. For the Venezuelans it is important to be able to show your hierarchical position, whereas the Danes do not care. What they are concerned with is to have a telephone, a fax and a computer at their disposal, so that they can work. In his cognitive representation of his Venezuelan colleague it does not occur to $L$ at all that the reason why he wants to measure his new office could have something to do with how to arrange his furniture in the room or something like that. $A$ even induces $L$ to repeat the gist of his story by her laughter. So implicitly the cultural attributions made by $A$ and $L$ focus on the Venezuelans being interested in the display of hierarchical positions and the Danes in work performance. That the interlocutors find themselves in the process of reaching an agreement on the adequacy of responses and shared understanding is further underlined by the shift in their use of speaker and hearer references. At the beginning of the sequence $A$ refers to $L$ with 'you' and $L$ to himself with 'I'. In the final 
stage of the negotiation process where an acceptable level of shared agreement should be arrived at, they both refer to each other with an inclusive 'we' reference.

Let us finally look at an example in which national identity is rejected as a valid category to account for differences in communicative behavior.

Example 3

Interviewer: A(nnette)

Respondent: C(hristina)

A: hvad med: hænger de sig i protokollen øh forstår du hvad jeg mener er der særlige: procedurer man altid skal følge særlige: arbejdsgange man skal følge og dem viger man bare ikke fra

C: ja men der er vi så nødt til og gå tilbage og sige det det øh 'her gør vi ikk fordi nu igen det der med at det er et ungt firma ikke også

A:

$\mathrm{mm}$

C: de firmaer vi arbejder med

det tager man ikke så højtideligt men

A:

$\mathrm{mm}$

C: $\quad$ hvor det faktisk er ældre indkøbschefer og så videre jo der er der meget protokol

A:

ok

Translation:

A: what about er do they stick to the protocol er do you understand what I mean are there special er procedures you always have to follow special routines you follow and you just don't abandon them

C: well then we are to go back and say it it er 'here we don't because now again the fact that we are a young company you know

A:

$\mathrm{mm}$

C: we don't take it

seriously but the firms we work together with

A:

$\mathrm{mm}$

C: where there actually are elderly purchasing managers and so on yes there is much protocol

A:

ok 
The thematic part of the question raised by the interviewer is similar to that of example 2 ('they' refers to the Venezuelans). Dynamically we find the earlier mentioned recipient design features. We even find a kind of person-oriented metastatement ('do you understand what I mean'?). What $C$ does in her reply is in the first place to generate a kind of metastatement, too, referring to something she said in reply to an earlier question ('well then we are to go back and say'). She takes up an earlier line of thought and categorically rejects that 'sticking to the protocol' forms part of Venezuelan cultural identity. Instead she introduces another set of membership categories, i.e. the younger and the older generation, where the category feature seems to apply. She is working in a young firm, where they do not stick to formalities, neither Venezuelans nor Danes. However, in Venezuelan firms with elderly staff they do. So, according to her point of view generation gaps are more important than national identity gaps to account for value mismatch. This is accepted as an adequate answer by $A$.

\section{Conclusion}

It has been argued that compared to the structured interview, the semistructured is better suited not to tell us something about how people act, nor what they think and believe in, but to explore the reasons why. However, since the semi-structured interview is accomplished in interaction between interviewer and respondent, it is important to gain insights into how they mutually manage to construct the interview. It has been suggested that useful terms to describe the discursive identities displayed by interviewer and respondent may be that of account recipient and accounter, respectively. Since the interviewer controls the interview process, another concern has been to analyze the degree to which he or she by his or her questioning behavior seems to activate specific types of responses concerning the respondents stereotypic beliefs and cultural identities. In their construction of accounts it turned out that both interviewer and respondent were very careful and attentive in their communicative choices. The respondents did not automatically accept the relevance of the categories and category features introduced by the interviewer, but showed great care and effort in offering true and accurate descriptions of how they gave meaning to their social world at the intercultural workplace. The interviewers on their part, demonstrated in their listening 
behavior that they tried to make sure that they had understood the respondents right. To offer true and accurate accounts and to ask clarifying questions and assess account contents are methods that may lead to a kind of intersubjectivity between interviewer and respondent that increase shared understanding and consistency within interviews, and not across interviews which is the major concern according to a structuralistic view of response generation.

\section{Transcription key}

$\begin{array}{ll}\text { ? } & \text { indication that an utterance is finished (falling intonation) } \\ ? & \text { rising intonation } \\ \text { (figure) } & \text { questioning intonation } \\ (\text { ) } & \text { pause } \\ \text { (word) } & \text { transcribers' guess } \\ :: & \text { prolonged sound } \\ (()) & \text { non-verbal activities, e.g. laughs } \\ {[} & \text { beginning of overlapping speech } \\ & \text { stress }\end{array}$

\section{References}

Antaki, Charles (1994). Explaining and Arguing - The Social Organization of Accounts. London: Sage Publications.

Antaki, Charles \& Widdicombe, Sue (eds.) (1998). Identities in Talk. London: Sage Publications.

Buttney, Richard (1993). Social Accountability in Communication. Newbury Park, Cal: Sage Publications

Fant, Lars M (2000). Managing social distance in interviews: a study on identity negotiation. Paper read at IprA conference, Budapest. 1-25.

Ford, Celia E. \& Thompson, Sandra A. (1996). Interactional units in conversation: syntactic, intonational, and pragmatic resources for the management of turns. In Ochs, Elinor \& Schegloff, Emanuel A. \& Thompson, Sandra A. (eds.) (1996) Interaction and Grammar. Cambridge: Cambridge University Press. 134-185.

Grindsted, Annette (2000). Stereotypes in action. In Odense Working Papers on Language and Communication 19. 33-51. 
Hager, Gregory et al. (1999). Southern Focus Poll. Training Manual. University of North Carolina.

Houtkoop-Steenstra, Hanneke \& Mazeland, Harrie (1985). Turns and discourse units in everyday conversation. In Journal of Pragmatics 9. 595-619.

Houtkoop-Steenstra, Hanneke (1995). Meeting Both Ends: Between Standardization and Recipient Design in Telephone Survey Interviews. In ten Have, Paul \& Psathas, George (eds.) (1995). Situated Order. Studies in the Social Organization of Talk and Embodied Activities. Washington, D.C.: International Institute for Ethnomethodology and Conversation Analysis \& University Press of America. 91-106.

Houtkoop-Steenstra, Hanneke (1997). Being friendly in survey interviews. In Journal of Pragmatics 28. 591-623.

Houtkoop-Steenstra, Hanneke (2000). Interaction and the Standardized Survey Interview. The living questionnaire. Cambridge: Cambridge University Press.

Hutchby, Ian \& Wooffitt, Robin (1998). Conversation Analysis. Principles, Practices and Applications. Cambridge: Polity Press.

Kvale, Steiner (1996). Interviews. An Introduction to Qualitative Research Interviewing. London: Sage Publications.

Mazeland, Harrie \& Have, Paul ten (1998). Essential Tensions in (Semi)-open Research Interviews. http://www.pscw.uva.nl/emcal/ET.htm. 1-12.

Mishler, Elliot G. (1986). Research Interviewing. Context and Narrative. Cambridge, MA: Harvard University Press.

Schegloff, Emanuel \& Sacks, Harvey (1974). Opening up Closings. In Turner, Roy (ed.) (1974) Ethnomethodology - Selected Readings. Harmondsworth: Penguin Modern Sociology.

Schegloff, Emanuel A. (1996). Turn organization: one intersection of grammar and interaction. In Ochs, Elinor \& Schegloff, Emanuel A. \& Thompson, Sandra A. (eds.) (1996) Interaction and Grammar. Cambridge: Cambridge University Press. 52-134.

Suchman, Lucy \& Jordan, Birgitte (1992). Validity and the Collaborative Construction of Meaning in Face-to-Face Surveys. In Tanur, Judith M. (ed.) (1992). Questions about Questions. New York: Russel Sage Foundation. 